hand-printing and weaving were on view. The arrangement of the exhibition would have reflected credit on the Royal Academy itself. All three members of the Bragg family have clearly found the painter's palette a valuable means of utilizing the little leisure at their command. Sir William Bragg, president of the Royal Society, showed an attractive study of aloes, while landscapes were also exhibited by his son, Prof. W. L. Bragg, Cavendish professor of physics in the University of Cambridge, and by his daughter, Mrs. Carol.

Major C. E. S. PHILlips, secretary of the Royal Institution, and Mrs. Phillips, are known by many to be artists of considerable taste. Between them they showed six of their many paintings, one of them being "On the Purbeck Hills", by Major Phillips, which was exhibited in this year's exhibition at the Royal Academy. A beautiful interior of the Cathedral Church of Christ, Oxford, was exhibited by Emily Vaughan Jenkins. One of the most interesting exhibits was a portrait of a spinster by Joyce Gardiner. The slightly embittered and very grim expression made the portrait live, and the title "Frustration" made the picture itself. Three landscapes by the late Dr. William Bateson, president of the British Association in 1914, and two by Mrs. Bateson showed an obvious love of rugged scenery. Three very beautiful paintings executed by the late Lady Robertson during the meeting of the British Association in Canada in 1924 were exhibited by Sir Robert Robertson, formerly Government Chemist. E. N. Willmer, lecturer in physiology in the University of Cambridge, is known to spend much of his holiday periods painting landscapes; here he showed three examples of what is clearly a successful and enchanting hobby. There is also a good portrait of Dr. F. F. Blackman, emeritus reader in botany in the University of Cambridge, by one of his colleagues, G. E. Briggs. Another by Briggs-“Cineraria"besides being a poem of colour, also brings out the plant physiologist in the painter. The wilting of the leaves and the florets is strikingly natural.

\section{Fossil Anthropoids in South Africa}

FUrTHER discoveries of the fossilized remains of anthropoids in South Africa, which were announced on behalf of Dr. Robert Broom of the Transvaal Museum during the meeting at Cambridge of the British Association (see p. 377 of this issue of NATURE), constitute an addition of the first importance to the evidence relating to the early history of man and his precursors which has been accumulating in South Africa since the discovery of Rhodesian man in 1921 and the later discovery in 1925 by Prof. Raymond Dart of the Taungs skull, Australopithecus africanus. The doubts which had been expressed whether the latter might not be a young chimpanzee or gorilla, and not, as Prof. Dart maintained, more closely related to the human stem than any fossil anthropoid then known, may be regarded as having been finally resolved by Dr. Broom's discovery of the Sterkfontein skull two years ago, to which he gave the name of Australopithecus transvaalensis, but for which his later discoveries now recorded lead him to adopt the significant nomenclature of Plesianthropus, expressing not only its generic difference from Australopithecus, but also its even closer relationship to man in the scale of development. This, however, does not close the tale of remarkable additions to our knowledge for which we are indebted to Dr. Broom. The story of how he rescued from the dangers of oblivion the fragments of still another and even more important relic, will command a tribute of admiration from all for his acumen and persistent energy in the pursuit of scientific discovery. He has been rewarded by the acquisition of what must be regarded as the most important piece of evidence now in existence relating to the evolution of man's ancestry. From fragmentary bones of the skull, the teeth, and the reconstruction of missing parts from the matrix, Dr. Broom has been able to reconstruct the Kromdraai skull, now classified as a new genus, Paranthropus robustus, and not merely coming closer in certain details to man than any previously known fossil anthropoid, but actually in line with man. Equally important is Dr. Broom's conclusion as to its dating, for he is now able to say, subject to further geological investigation, that while Australopithecus is regarded as probably Lower Pleistocene, the Kromdraai skull is Middle, and the Sterkfontein skull Upper Pleistocene.

\section{Russian Astronomers}

The Polish journal Acta Astronomica, in its July issue, states that the following members of the staff of the Pulkovo Observatory have been imprisoned: I. A. Balanovsky, N. I. Dneprovsky, B. P. Gerasimovič (director), P. I. Iaschnoff, B. W. Noumeroff (director of the Astronomical Institute at Leningrad, who is believed to have been shot), N. W. Zimmermann. The Editor of Acta Astronomica states that it would give him great pleasure to be able to refute this statement, a sentiment which we are sure scientific workers everywhere will echo.

\section{Backward Peoples: a Proposal from Holland}

The Netherlands Commissie voor Internationale Natuurbescherming (Netherlands Committee for the International Protection of Nature) has prepared through its recently constituted Committee for the Preservation of Primitive Races a general statement of the problem with special reference to the primitive peoples of the Dutch possessions in New Guinea. To this are added some suggestions as to how best to deal with the difficulties which will arise, or have already arisen, if and when peoples living in the stone age, who in some instances previously were not even aware of the existence of the white man, are suddenly brought into contact with the blessings (aeroplanes, motor-cars, radio) and the curses (alcohol and venereal disease) of Western civilization. A useful point is made, frequently overlooked, that an even greater danger than the white man in the matter of exploitation is the neighbouring native people of slightly higher culture which has assimilated or acquired some of the elements of white civilization. This statement of the problem is restrained, but well informed. Its 
details will be familiar to those who have studied the effects of contact between primitive and Western culture and the irreparable disasters which have followed upon such contacts in the last hundred years.

Is putting forward certain suggestions as to how best to deal with the situation in areas in which the natives are at present virtually untouched, such as parts of New Guinea, the islands of New Britain, and the Congo, two principles are enunciated, one ethical, namely, that the ruling power must not restrict the natives' opportunities of ordered cultural development, the second that in the interests of science opportunity should be preserved for study of native cultures before they are hopelessly corrupted by unregulated contact with the worse elements in Western civilization. Accepting the view that the interests of the native should be the first consideration, since commerce and industry may be trusted to look after themselves, the committee suggests that reserves should be created, not for the preservation of native tribes and cultures as museum pieces, but in order that these backward peoples may be led to develop gradually under supervision and strict regulation of contacts, cultural and other, in a slow but healthy upward progression, in which the elements of their own culture will be assimilated in higher forms of eivilization. It will be seen that the ideal formulated by the Dutch Committee is sufficiently in accord with the views of those in Great Britain, who press for a scientific approach to the problem of the future of backward peoples, to warrant co-operation in the attainment of what is the common end. In any event, they will agree with the committee that the problem is urgent and immediate.

\section{Jubilee of the American Mathematical Society}

THE fiftieth anniversary of the founding of the American Mathematical Society, which is being celebrated early in September at Columbia University, New York City, in connexion with the annual summer meeting of the Society, is unusual among jubilees of learned societies in that the principal founder of the organization in 1888 is serving as chairman of the committee in charge of the jubilee celebrations. Prof. Thomas Scott Fiske, now emeritus professor of mathematics in Columbia University, took the initiative in bringing together six mathematicians fifty years ago to establish the New York Mathematical Society, having received his inspiration to do this from his attendance at meetings of the London Mathematical Society while a student at Cambridge the preceding year. Dr. Fiske, as secretary of the young society, was indefatigable in his efforts to increase its membership, and succeeded so well that in 1891 the Society was strong enough to begin publication of the Bulletin of the New York Mathematical Society, which has been continued to the present time as the official organ of the Society, its name, of course, having been changed to correspond to the change in name of the Society to American Mathematical Society in 1894.

IN 1900, the journal entitled Transactions of the American Mathematical Society was established by the Society for the publication of research papers. In the course of time the service of the Society to its membership in the promotion of mathematical research has come to include also an annual course of lectures on recent advances in some specific field of mathematics, and the publication of these in a series of Colloquium Publications, now numbering twenty-four volumes, the Josiah Willard Gibbs lectureship on applied mathematics, the maintenance of a library especially strong in relatively obscure journals, the award from time to time of several endowed prizes and the holding of ten or more meetings annually for the communication of approximately five hundred research papers. For many years Columbia University has provided office space for the Society, and more than half the regular meetings of the Society have been held in the University.

\section{The Centro Volpi di Elettrologia}

Count Voupr di Misurata, whose name is associated with many important Italian electric companies, has decided, in the interests of science, to create an institution in Italy to promote the knowledge of, and research in, electrical science. He has presented the magnificent Vendramin-Calergi Palace in Venice to serve as a home for the new institution which will be known as the Centro Volpi di Elettrologia after its founder. It is so arranged that it works in harmony with other existing Italian scientific societies. Its principal object is the improvement of electrical knowledge by means of new cultural exchanges between Italian and foreign scientists. Its main activities will be to publish a bulletin giving summaries of recent Italian researches, translated into various languages in different editions for distribution abroad. It will also promote international congresses and meetings of men of science in the quiet Venetian palace so that they may advance electrical knowledge by exchanging ideas on specific scientific questions.

WE have received a copy of the first bulletin of the Centro Volpi di Elettrologia in English. It illustrates briefly the activities of and the schemes initiated by the Centro Volpi. It reports in the form of short abstracts all Italian publications dealing with electrical subjects. Great pains have been taken with the documentation of the bulletin. Each abstract is of such a size that it can be cut and gummed on an international card in accordance with the resolutions and recommendations of the World Congress of Documentation. Later on, should some article appear which is important either on account of new ideas or results, or because it serves as a basis for cultural exchanges, an amplified summary will be given in addition to the usual notice. In this bulletin an interesting article on "Acoustical Research in Italy" is given. The plans and sections of the new acoustic laboratory in the national electrotechnical institute 'G. Ferraris' in Turin is described. At present the laboratory has in use four reverberating rooms and two sound-absorbing rooms. When completed it will have a sound-proof room for microphonic calibrations and acoustimetric experiments. 